\title{
THE SCALE OF THE MOBBING PROBLEM AMONG PARAMEDICS IN THE UNITED STATES AND POLAND
}

\author{
Togay Evrin ${ }^{1}$, Marcin Madziala ${ }^{2}$ \\ ${ }^{1}$ Department of Emergency Medicine, UFuK University Medical Faculty, Ankara, Turkey \\ ${ }^{2}$ Department of Emergency Medicine, Medical University of Warsaw, Poland
}

\begin{abstract}
BACKGROUND: In the last several years the problem of mobbing has drawn noticeable attention among members of society. In particular, one of the groups which have become a subject of mobbing comprises paramedics. This study aims to define the scale of mobbing among paramedics working in Poland and in the United States of America.

METHODS: The present study was performed by the means of a diagnostic survey among 2,135 paramedics working in Poland and the United States of America.

RESULTS: The obtained results show that mobbing is widespread among paramedics working both in Poland and the US (83.68\% and $30.79 \%$, respectively), while it was most frequently pointed out that the perpetrator was a supervisor (52\% and $35 \%$, respectively). A positive correlation was observed between the intensification of the process of mobbing and the young age, female gender and shorter work experience of the victim.

CONCLUSIONS: Mobbing is a significant problem in the work of paramedics, while the scale of the occurrence of this phenomenon may indicate inadequacies in the process of management of human resources within paramedic teams.
\end{abstract}

KEY WORDS: mobbing, paramedic, work

Disaster Emerg Med J 2016; (1)1: 50-54

\section{INTRODUCTION}

Although workplace violence is not a new phenomenon, only in the last several has it received wider attention among members of society. The term mobbing comes from the word "to mob" which means to jostle, or to annoy or to attack [1]. The term "mobbing" was used for the first time by K. Lorenz in the context of animal behaviour [2]. Lorenz observed a group of small and weaker animals threatening a single larger animal in order to scare it away. In 1982, Leymann used the term "mobbing" concerning the psychological reactions at the workplace [3], which included harassment, humiliation, and ridicule by co-workers or by superiors.

Apart from the fact that although the occurrence of aggression at the workplace may take different forms, it is certainly a factor which affects mental health, work motivation, and work efficiency a great deal. It is worth paying attention to the fact that, paradoxically, mobbing most frequently affects those who are among the best and most effective workers, as well as young people possessing higher education, rather than the average members of the team. 
While the last two decades have given us quite a lot of information about the mobbing phenomenon within different professional groups, paramedics are a professional group in which the scale of the mobbing problem has never been researched. Thus, this study aims to define the scale of mobbing among paramedics working in Poland and the United States of America.

\section{METHODS}

The survey trial was chosen on purpose while the participants were paramedics who were employed by Emergency Medical Services in Poland and in the United States of America. Participation in the survey was voluntary.

A survey was conducted from January to November 2013. Persons who participated in the survey were sent, by means of an e-mail, a questionnaire especially prepared for this research. A diagnostic survey included an NAQ [4] questionnaire, which is used for measuring perceived exposure to mobbing at work. The first part of the questionnaire contained items regarding negative actions while the second part measured the overall feeling of being mobbed. The NAQ questionnaire is a survey tool with a high coefficient of internal consistency (Cronbach's alpha $=0.94$ ). In the research, in addition to the objective identification of exposure to mobbing at work based on the NAQ questionnaire (items 1-22), a subjective method of estimation through personal feelings, which were expressed by the interviewees in item 23, was also used.
In total, 2500 questionnaires were sent out. The number of the questionnaires returned varied, depending on the country, and it ranged between $63 \%$ for the USA up to $91 \%$ for Poland. A total number of 1,820 questionnaires from Poland and 315 from the USA were qualified for analysis having in mind the quality of the filled-in information (no data). The average age of the person interviewed was 28.53 years. Details regarding the examined group are shown in Table 1.

The obtained results were developed with the help of Microsoft Excel software and the Statistica v. 10 software package for Windows. In order to evaluate the significance of the differences between the analyzed populations of paramedics, a chi ${ }^{2}$ test was used [5].

\section{RESULTS}

A correlation between being exposed to mobbing at work (both by the objective method, that is the onetime method; and the subjective method, which involves the feeling that a person is being mobbed) and selected socio-demographic data was analyzed using the chi-square test. The obtained results are shown in Table 2.

As a result of the above-mentioned analysis, there is a correlation between the variable "age" and the objective feeling of being exposed to mobbing. Persons who felt mobbed at work were of a younger age. Regarding gender, the statistics show that women felt exposed to mobbing more often than men. Both methods, namely objective and subjec-

\begin{tabular}{|c|c|c|}
\hline \multirow{2}{*}{ Parameter } & \multicolumn{2}{|c|}{ Value } \\
\hline & Poland & USA \\
\hline Age, mean $\pm S D$ & $27.66 \pm 4.12$ & $31.23 \pm 2.43$ \\
\hline $\begin{array}{c}\text { Gender, } \mathrm{n} \\
\text { Male } \\
\text { Female } \\
\text { Total }\end{array}$ & $\begin{array}{c}1365(75 \%) \\
445(25 \%) \\
1820(100 \%)\end{array}$ & $\begin{array}{l}214(67.4 \%) \\
101(22.6 \%) \\
315(100 \%)\end{array}$ \\
\hline Work experience, mean \pm SD & $7.54 \pm 4.58$ & $10.21 \pm 6.42$ \\
\hline
\end{tabular}

SD - Standard Deviation

\begin{tabular}{|c|c|c|c|c|}
\hline \multicolumn{2}{|c|}{ Table 2.Correlation between exposure to mobbing and variables } \\
\hline Method & Age & Gender & $\begin{array}{c}\text { Duration of } \\
\text { employment }\end{array}$ & Country \\
\hline Objective method & $-0.28^{*}$ & $0.21^{*}$ & $-0.24^{*}$ & $0.23^{*}$ \\
\hline Subjective method & -0.17 & $0.2^{*}$ & $-0.26^{*}$ & $0.27^{*}$ \\
\hline
\end{tabular}

${ }^{*} p<0.05$ 
tive, are correlated with the country of employment. Paramedics working in Poland more often felt exposed to mobbing than persons working in the US. The level of feeling exposed to mobbing was relevantly dependent of one's short work experience.

The key component regarding one's perception of mobbing is the matter of defining it properly. Accordingly, a definition of mobbing was included in the questionnaire, based on which $83.68 \%$ $(n=1523)$ paramedics working in Poland and $30.79 \%(n=97)$ paramedics working in the US acknowledged that mobbing was present in their working environment.

Details regarding the correlation between the presence of mobbing and age are pictured in Figure 1.

A difference was observed in answers regarding the intensity of the occurrence of mobbing among interviewees. The intensification of occurrence of mobbing among paramedics from Poland and the USA is shown in Figure 2.

As a result of the carried-out analysis, besides differences in the overall number of cases of mobbing regarding countries in question, there are also apparent differences in the intensification of the occurrence of mobbing. In Poland mobbing occurs more often than in the US, and the intensification of occurrence of mobbing is also considerably higher in Poland.

As an answer to the question of who is most often the perpetrator, interviewees most often pointed to superiors, next to several persons at the same time $(32 \%$ vs. $22 \%)$, co-workers $(12 \%$ vs. $5 \%)$ or other persons ( $4 \%$ vs. $12 \%$ ). The above-mentioned data is shown in Figure 3.

\section{DISCUSSION}

According to scientific literature, both in Poland and the United States of America, research regarding mobbing among paramedics has never been carried out before. The available data usually concerned nurses and, to a lesser extent, doctors. Ever-changing legal regulations regarding the overhaul of health care, as well as job insecurity, along with job loss, are among factors that have facilitated the occurrence of this kind of phenomenon.

According to Eirnarsen [6], mobbing is defined as negative, oppressive and at the same time humiliating actions or organizational procedures permanently directed towards a section of employees. Similar observations were extrapolated by Leymann $[3,7]$, who, among factors responsible for

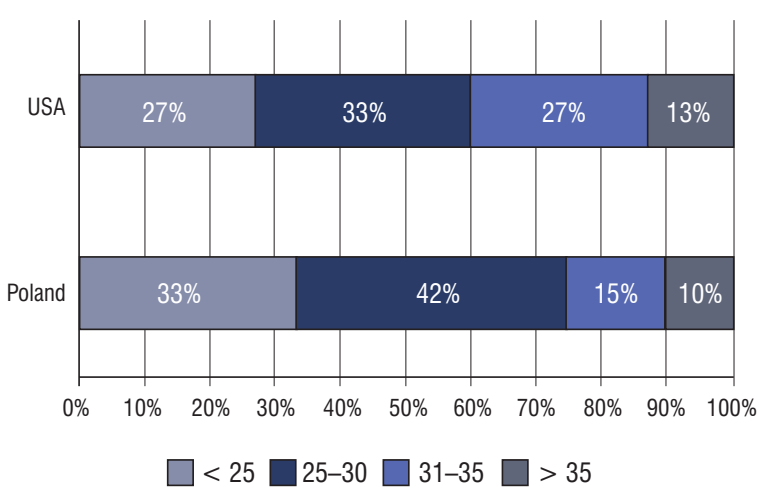

FIGURE 1. The scale of the occurrence of mobbing within the examined group with the variable "age" taken into consideration

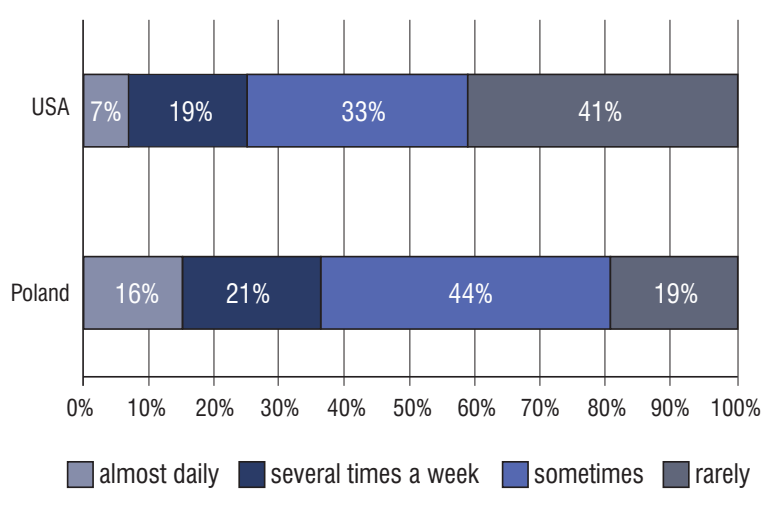

FIGURE 2. The intensification of the occurrence of mobbing within the examined group

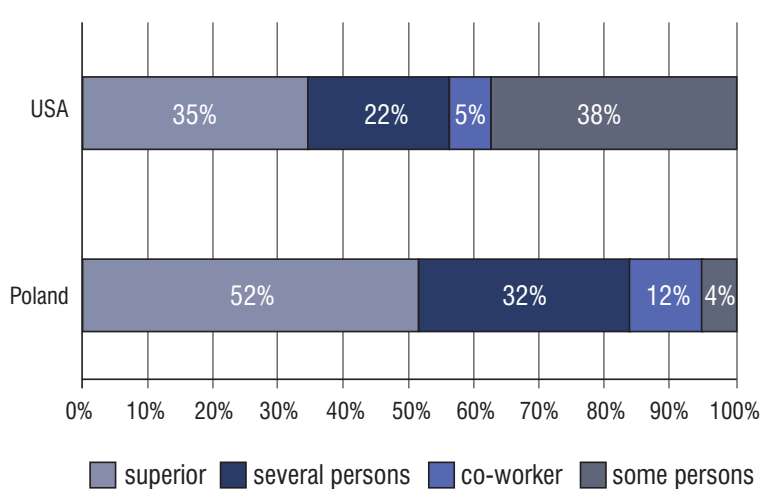

FIGURE 3. The perpetrator of mobbing according to those being mobbed

mobbing, named an organizational culture which condoned and sometimes even encouraged a person/persons to perform actions based on harassment and ridiculing a chosen group of workers.

A study, which was carried out in 2002 by the Nofer Institute of Occupational Medicine in Łódź (Poland), shows that among a group of 1,163 nurses, $5.6 \%$ of them had been subjected to mobbing during the previous year by their co-workers [8]. Studies which were carried out among nurses working in 
Szczecin (Poland) by other authors indicated 18.6\% of them had been subjected to mobbing [9]. Data obtained in the study regarding the scale of the mobbing problem among paramedics in Poland shows that the scale of mobbing in Poland is almost three times higher than in the US $(83.68 \%$ and $30.79 \%$ accordingly). As far as Poland is concerned, the obtained result is significantly higher than those results obtained in a study regarding nurses and their exposure to mobbing. In the scientific literature there are significant differences in obtained results regarding studies on the scale of mobbing experienced (Milutinovic - 14\% [10], Fornes-Vives - 17.2\% [11], Ozturk $-25 \%$ [12], Efe - 33\% [13], Yildirim - 86.5\% [14], Sahin - 87.7\% [15]). In her studies, Zdziebło showed that $72 \%$ of nurses encountered the phenomenon of mobbing in the work place, whereas $41.1 \%$ of nurses had been subjected to mobbing [16].

It is worth paying attention to the fact that $35.36 \%(n=673)$ of interviewed paramedics acknowledged that they had been subjected to mobbing very often (every day or several times a week). From the analyses of our own research, it can be seen that most often the perpetrator (tormentor) is a superior $(49.46 \%, n=1056)$, while in research carried out by Dalikowska, it was shown that this was the situation in $20.88 \%$ of cases. In research conducted by the Pomeranian Democratic Institute $58.9 \%$ [8] and in research carried out by Kunecka - 40\% [9], Cevik - 57\% [17].

There is no such profession which may be considered completely free from the phenomenon of mobbing. The risk of its emergence may be determined by various factors such as age, gender, level of education, or even form of employment [18].

According to the literature, younger age is conducive to the occurrence of mobbing $[17,18]$, a fact which has been proven by our research carried out on paramedics working in Poland and the United States. However, neither Kunecka [9] nor Sahin [15] confirmed such a relationship in their research. Moreover, Kunecka showed that the people most often subjected to mobbing were those with the least work experience, which is confirmed by our own research. The results obtained in this study show that women are more often subjected to mobbing, a fact which has been also confirmed by research conducted by Hirigoyen [19]. In addition, higher incidence of mobbing-type behaviour toward men was observed by Kunecka [9] and Fornes-Vives [11].
In order to counteract mobbing, it is important to provide an appropriate working ambiance and good interpersonal relations since in the first place, as stated by Warecki [20], mobbing is primarily a moral problem which is a result of unsatisfactorily solved problems occurring among co-workers.

\section{CONCLUSIONS}

1. Paramedics are subjected to mobbing in their workplaces.

2. The occurrence of mobbing among paramedics in Poland is almost three times higher than in the US.

3. There is a need for a permanent diagnosis of the phenomenon of mobbing, as well as the development of preventive measures which will be aimed at preventing the occurrence of acts of violence at work.

Conflict of interest: None declared.

\section{REFERENCES}

1. Resch M, Wenn Arbeit krank macht. Ullstein Buchverlage, Berlin 1994.

2. Dietl HM, Stange W. Pretensions of a behavior scientist and the logic of science on K. Lorenz' attempt to transfer the statements of behavioral sciences to human society. Z Arztl Fortbild (Jena), 1971; 65(19): 1093-1096.

3. Leymann $\mathrm{H}$. The content and development of mobbing at work. European Journal of Work and Organizational Psychology, 1996; 5(2): 165-184.

4. Notelaers $G$, Einarsen $S$, De Witte $H$, Vermunt JK. Measuring exposure to bullying at work. The advantages and validity of the latent class cluster approach. Work \& Stress, 2006; 20(4): 288-301.

5. Bagdonavicius V, Nikulin MS. Chi-square goodness-of-fit test for right censored data. JAMAS, 2011; 24: 30-50.

6. Einarsen S. Bullying at work: the Norwegian lesson w: Bullying at work research update conference: Proceedings. Rayer C, Sheehan M, Barker M. (red.), Staffordshire University, Stafford 1998; 11-27.

7. Leymann H. Mobbing. Psychoterror am Arbeitsplatz und wie man sich dagengen wehren kann. Rowohlt Verlag, Hamburg 1993.

8. Mościcka A. Bullying in the workplace - a special type of occupational risk. Problems of occupational hygiene. PTH. Wroclaw 2006; 221-231.

9. Kunecka D, Kamieńska M, Karakiewicz B. The scale of the phenomenon of bullying among nurses/nurses employed in hospitals in Szczecin. Med. Pracy, 2008; 59(3): 223-228.

10. Milutinović D, Prokes B, Gavrilov-Jerkovié V, Filipović D. Mobbing - special reference to the nursing profession. Med Pregl, 2009; 62(11-12): 529-533.

11. Fornés-Vives J, Martínez-Abascal Martínez MA, García-Banda García $G$. Socioprofessional variables involved in mobbing in nursing. Enferm Clin, 2008; 18(3): 127-133. 
12. Ozturk H, Sokmen S, Yilmaz F, Cilingir D. Measuring mobbing experiences of academic nurses: development of a mobbing scale. J Am Acad Nurse Pract, 2008; 20(9): 435-442. doi: 10.1111/j.17457599.2008.00347.x.

13. Efe $S Y$, Ayaz $S$. Mobbing against nurses in the workplace in Turkey. Int Nurs Rev, 2010; 57(3): 328-334. doi: 10.1111/j.14667657.2010.00815.x.

14. Yildirim A, Yildirim D. Mobbing in the workplace by peers and managers: mobbing experienced by nurses working in healthcare facilities in Turkey and its effect on nurses. J Clin Nurs, 2007; 16(8): 1444-1453.

15. Sahin B, Cetin M, Cimen M, Yildiran N. Assessment of Turkish junior male physicians' exposure to mobbing behavior. Croat Med J, 2012; 53(4): 357-366.
16. Zdziebło K, Kozłowska E. Mobbing the work environment of nurses. Problemy Pielęgniarstwa, 2010; 18(2): 213-218.

17. Çevik Akyil R, Tan M, Saritaş $S$, Altuntaş $S$. Levels of mobbing perception among nurses in Eastern Turkey. Int Nurs Rev, 2012; 59(3): 402-408. doi: 10.1111/j.1466-7657.2012.00974.x.

18. Fornés-Vives J, Martínez-Abascal Martínez MA, García-Banda García G. Socioprofessional variables involved in mobbing in nursing. Enferm Clin, 2008; 18(3): 127-133.

19. Hirigoyen MF, Harassment at work, transl. Żerańska M. Wydawnictwo W drodze, Poznań 2003.

20. Warecki W, Warecki M. A word about bullying, or how to deal with a bully, Wydawnictwo Poltext, Warszawa 2005. 